\title{
The uterus, an organ of many roles
}

\author{
P.D. Rossdale
}

Beaufort Cottage Stables, Newmarket, UK

\section{Introduction}

The uterus is a somewhat unique mammalian organ, essential to reproduction but of no consequence to survival of the individual per se. It may be removed surgically for convenience or, in the event of pathology, necessitating hysterectomy. The equine veterinary clinician has devoted increasing attention to the clinical aspects of uterine function and dysfunction as the basis for the individuals sub- or infertility since the early 30 's, when gynaecology became a routine procedure in studfarm practice. The relationship of metritis with bacterial infection was noted in the 20's (Dimmock and Edwards, 1927,1928) and has remained a focal point of interest to clinicians worldwide.

One of the most significant contributions to the prevention and cure of endometritis was provided by Caslick (1937). The Caslick operation (vulvoplasty) may be justly regarded as the one single most decisive therapeutic measure of importance compared to that of any other proposed or developed during the past century with respect to improving the breeding potential of brood mares. No other single measure has been as decisive in restoring the genital tract to comparative normality. The uterus is the seat of productivity as far as breeders are concerned: hence the clinical interest in the organ as to its physiological role and the pathology which affects its function. Of course, there are variables which play a higher role, no ova for example nullify the uterine role and create a state of non-productivity. There is also the influence on and interrelationship with the reproductive processes supplied and controlled by the endocrine system. The uterus also occupies an anatomical connection with the ovaries internally via the oviducts and the cervix, vagina and vulva leading externally.

The functions of the uterus are largely external, despite its placement within the confines of the abdomen. Semen is deposited in its lumen and spermatozoa travel its length in order to reach the ovum, once shed, within the oviduct. The lumen then receives the fertilised ovum and establishes a relationship with the fetal membranes (placenta). The fetal, en dometrial, myometrial and maternal relationships are those of intimacy, but nevertheless the fetus remains within the lumen of the organ until expelled at parturition. It has been likened to a parasite - receiving nourishment while contributing little. The myometrium plays an essential role in the expulsion of the fetus through the birth canal. Nonetheless, the organ is not essential to the life of the mare, only to the 'creation' and life of the fetus; hysterectomy leaves the individual with no deficit apart from the loss of reproductivity.

Therefore, the uterus plays a passive role, allowing access by the sperm to the ovum, accepting the fertilised ovum in- to its cavity and, for 11 months, moulding itself to the growing parasite of the fetus and its membranes until such time as the 'parasite' reaches the maturity that provides a chance of successful adaptation to the extrauterine environment; and then partaking in the act of parturition by virtue of its contractility which initiates the process of birth and then returns the organ to its non-pregnant size and state within a matter of weeks post partum.

\section{The clinician's approach}

The gynaecology of the mare is a clinical art and science which recognises the crucial role played by the uterus in the process of reproduction and, particularly, as a signpost to the diagnosis of sub-fertility; and hence to the need for accumulating diagnostic criteria and the means of therapy and prophylaxis. In addition, in the arbitrary world of horse breeding where man, rather than nature, has come to occupy a decisive role in the management of mating and control of the oestrous cycle, knowledge of the sexual functions of the reproductive processes of the mare has become, rightly or wrongly, an essential role of veterinarians. Within this system, the diagnosis of oestrus, dioestrus, anoestrus and pregnancy have become a prerequisite to the specialisation of veterinarians in equine studfarm medicine. The pioneers of gynaecology in the mare were Dimmock and Edwards in the USA, Day in the UK, Merkt in Germany and Mahaffey in Australia. In the post war era, examinations of the mare pre- and post coitus for her sexual state and of the genital tract for evidence of pathology has become routine worldwide.

The uterus can be palpated per rectum, viewed by ultrasonography (Palmer and Driancourt, 1980; Chevalier and Palmer, 1982; Simpson et al, 1982) and, more recently, by scintigraphy (LeBlanc et al, 1994a, 1994b), its lumen inspected by endoscopy (Brandt and Manning, 1969; Mather et al, 1979) and its secretions collected directly or indirectly (from the cervix) to be examined by bacteriology (Hunt and Rossdale, 1963; Merkt et al, 1980 and 1987) and cytology (Knudsen, 1964; Wingfield Digby, 1978), and the endometrium examined via the technology of biopsy specimens subjected to light (Kenney, 1975, 1978; Ricketts, 1975, 1978) and ultramicroscopy (Samuel et al, 1979). It is not surprising, therefore, that the organ is the object of a great deal of clinical scrutiny by veterinarians. Apart from the information that can be obtained, the principle of 'have technology must employ' is the trendsetter of clinical acumen in medical and veterinary medicine (Rossdale, 1988). 


\section{Infection, endometritis, metritis and venereal disease}

As with all medical and veterinary terminology, truth lies in the eye of the beholder; and the beholder may be a clinician, bacteriologist, physiologist, immunologist or owner. In any discussion of the subject there is, as always, a need to define terminology before a dialogue can usefully take place.

The subject, in the modern era, extends back to the 1920's when Dimmock and Edwards (1928) contributed to Bulletin Number 286 of the Kentucky Agricultural Experiment Station, University of Kentucky, on the 'pathology and bacteriology of the reproductive organs of mares in relation to sterility'. In this the authors concluded:

1. Bacteriological examinations of the cervix and uterus of barren mares is the most reliable method of determining the presence or absence of infection.

2. Bacteriology is essential to differentiate between different kinds of infection.

3. Approximately one third of all barren mares examined were found to be suffering from either a severe or mild form of cervicitis or metritis due to infection.

4. Most non-infected mares are consistently negative on culture; most infected barren mares are consistently positive on culture.

5. Most mares suffering from uterine infection will fail to conceive when bred.

6. Streptococci are the most common form of infection.

7. Encapsulated bacilli (Friedlander's bacillus: now Klebsiella pneumoniae) causing metritis in mares may be transmitted from mare to mare by the stallion at the time of service.

8. Stallions do not become permanent carriers of the infection.

9. Barren mares, free from infection of the genital tract, are more resistant to infection at the time of service than are foaling mares.

10. The prevention of streptococcal and other forms of infection from the genital tract of mares is fundamentally a question of sanitation and breeding hygiene.

In the 70 years since this publication these statements still stand, although the emphasis of certain aspects has changed fundamentally. This is particularly the case with the term infection. Whereas the proportion of mares found positive on cervical and uterine culture has been confirmed and remains roughly in the order of $30 \%$ (Ricketts et al, 1993) clinicians and bacteriologists require further confirmation of infection than culture alone. For this reason, the term endometritis has been introduced. This, rightly, implies the presence of an inflammatory process in addition to the presence of bacteria. Endometritis may be identified by the presence of polymorphonuclear leucocytes in cytology of the cervix and/or uterus (Knudsen, 1964; Wingfield Digby, 1978; Brook, 1993); and in the histopathology of uterine biopsies (Kenney, 1975; Ricketts 1975).

Further definition of the terminology of infection was necessitated by mini- or major epidemics of uterine infections associated with Klebsiella (Dimmock and Edwards, 1927), Pseudomonas (Anon, 1965; Hughes et al, 1966), and Tay- lorella equigenitalis (Powell et al, 1978; Taylor et al, 1978; Hazard, 1979) in the 1960's and 70's.

This led to the development of the concept that certain bacteria could be readily transferred from mare to mare via the stallion or by handling or utensils, such as speculum, thereby establishing an endometritis in previously healthy individuals. These so called venereal organisms are specifically Pseudomonas pyocyanea, Klebsiella pneumoniae and the contagious equine metritis organism Taylorella equigenitalis. These organisms may colonise the genitalia of stallions but do not often cause infection, if infection is defined as a process involving associated inflammation. There are few reports of stallions being thus affected (Crouch et al, 1972). The organisms are therefore venereal in the sense that they are transmitted by coitus.

However, a further dimension to the subject is the recognition that these organisms vary in their pathogenicity (ability to initiate uterine inflammation). In the case of Klebsiella it appears that only capsule types 1,2 and 5, out of the many capsular types known, are actually transferred at coitus. Capsular type 7 , which is a very common coloniser of the external genitalia of stallions, is rarely transmitted. Pseudomonas also appears to vary in this respect.

A further complication to this subject of venereal infection is the fact that some mares are more susceptible to infection than others. The concept of the susceptible mare stems from work performed by Hughes and Loy, 1969 and Kenney et al, 1975; and has further expanded the clinical interest into immunology (Asbury et al, 1982; Widders et al, 1984; Cheung et al, 1985; Asbury and Hansen, 1987, Watson et al, 1987; LeBlanc et al, 1991). Interest in myometrial activity (Taverne et al, 1979; Troedsson et al, 1995) and uterine drainage (fluid accumulation) (LeBlanc, 1994a, 1994b) has become a recent focus of clinical interest.

\section{Current practices}

Where then are we today? There have been numerous studies in the past two decades regarding the pathogenesis of endometritis in the mare. It may be said there is currently a research explosion on these matters. However, the medical aphorism that 'the patient is a case of one' still applies. Are there individuals, therefore, that we can truthfully claim to have conceived and carried to full term as a result of our understanding of uterine physiology and pathology, which would not have done so without the therapy and management that follows from this understanding? There are studies based on statistics which suggest that this is indeed the case.

However, there is undoubtedly a genetic influence which is frequently over looked and understudied, particularly where selection is based, as in the Thoroughbred, on athletic performance and not with the aim of achieving fertility. Earlier, the writer has put forward the view that the Caslick vulvoplasty operation was the single most important contribution to the problem of solving endometritis in the mare. But the need for this surgery rests upon conformation of the perineum and, as Pascoe (1979) and Ricketts (1987) have 
shown, poor conformation is a potentially heritable condition. Indeed, in the breeding of Thoroughbreds we have already arrived at the need for further surgery in the form of the operation described by Pouret in 1982.

The irony of today is, perhaps, that research leads to the promotion of the incidence of reproductive defects which, in turn, require further research. The uterus plays a central role in this process of research versus practical procedures. And it is reasonable to assume that endometritis results from a breakdown in the non cellular defence mechanisms or the failure of intra cellular killing of bacteria by phagocytic cells (Peterson et al, 1969), or the need for minimal contamination techniques for breeding mares (Kenney et al, 1975). Also there is undoubtedly a relationship between ovarian hormones and uterine infection (Rowson et al, 1953) and the lesson of Hughes and Loy (1969), that the mares uterus is normally capable of eliminating bacterial contamination at coitus, should not be lost in relation to management practices and the selection of individuals within the herd for breeding purposes.

\section{Pregnancy}

The biggest challenge to the uterus is pregnancy. To house and nourish a fertilised ovum that grows exponentially from a morula measured in millimetres to a fetal foal and its membranes weighing well over $50 \mathrm{~kg}$ in total is a miracle of accommodation. This accommodation is based on adaptation of the myometrium and collagen content on which tone and form of the organ depend in a way which changes the dimensions from centimetres to metres; and returns the organ to its original size post partum. Further accommodation is required of the endometrium itself with the demands of greatly increased vascular and glandular activity during the 11 months of gestation.

The greatest challenge to reproductive efficiency is, perhaps, that of pregnancy itself. And this is well recognised in clinical terms in mares which fail to recover from an abnormal pregnancy and which may change a previously highly reproductive individual to one of sub-fertility (Rossdale, 1980). Studies have shown that chronic degenerative changes parallel the reduction of fertility according to the number of pregnancies the individual has undergone (Ricketts and Alonso, 1991). In addition, the uterus appears to age even in the absence of pregnancy (Finn and Porter, 1975). There are, therefore, two distinct processes, age and parity, which influence the fertility of individuals. It is probable, however, that genetic influences play a part in the process of deterioration and selection is, therefore, again an element that we must take into account in the management of brood mares.

\section{Conclusions}

The uterus is an essential organ of reproduction and a rightful focus of interest for clinicians and research workers. The future will undoubtedly bring further understanding of the pathology of this organ and also in the means of assessing its natural processes and their dysfunction. At some stage notice will have to be taken of the hereditability of these dysfunctions and some effort made to redress the balance of nature versus management. In philosophical terms, 'if you sup at the devil's table you must drink the devil's brew'; and we must not allow the equine uterus to become primarily an organ of research and clinical acumen rather than one of reproductivity.

At some stage in the near future the research currently in progress on the equine genome (Guerin et al, 1994; Bailey et al, 1995) will achieve objectives (Klemetsdal, 1990; Mart et al, 1991, 1992; Marti and Binns, 1997). The knowledge, gained from use of microsatellites, may point the way towards identifying undesirable traits within the horse population, thereby offering breeders the opportunity to select for the elimination of inherited defects.

Although subfertility is based upon a pathogenesis of many factors, clinical experience suggests that endometritis, as with poor perineal conformation, runs in families as does subfertility in general. If we can define the component parts of the patchwork in terms of anatomy, immunology and/or endocrinology, the way ahead for breeders may be to attach some, if not equal importance, to selecting matings for fertility as for athletic performance.

The only alternatives to this approach will be to suffer subfertility or to move towards embryo transfer which enables genetic material arising from a given mating to be housed within a uterus of a mare which has been selected for its physiological excellence and absence of pathology. Those responsible for the rules of Thoroughbred breed societies may leave at this point!; but, in considering the future, we can only bear in mind the words of the poet Tennyson 'for I dipped into the future far as human eye could see, saw the vision of the world and all the wonders that would be'.

\section{References}

Anon. (1965): Report on uterine infection in mares. Vet. Rec. 77, 110-111. Asbury, A.C., Schultz, K.T., Klesius, P.H., Foster, G.W. and Washburn, S.M. (1982): Factors affecting phagocytosis by neutrophils in the mare's uterus. J. Reprod. Fert. Suppl. 32, 151-159.

Asbury, A.C. and Hansen, P.J. (1987): Effects of susceptibility of mares to endometritis and stage of cycle on phagocytic activity of uterine-derived neutrophils. J. Reprod. Fert. Suppl. 35, 311-316.

Bailey, E., Graves, K.T., Cothran, E.G., Reid, R., Lear, T.L. and Ennis, R.B. (1995): Synteny-mapping horse microsatellite markers using a heterohybridoma panel. Animal Genetics, 26, 177-180.

Brandt, G.W. and Manning, J.P. (1969): Improved uterine biopsy techniques for diagnosing infertility in the mare. Vet. med. Small anim. Clin. 66, 977-983.

Brook. D. (1993): Uterine cytology. In: Equine Reproduction. Eds. McKinnon A.O. and Voss, J.L. Pubs. Lea and Febiger, Philadelphia, London, 246-254

Casilick, E.A. (1937): The vulva and the vulvo-vaginal orifice and its relation to genital health of the Thoroughbred mare. Cornell Vet 27, 178-187

Chevalier, F. and Palmer, E. (1982): Ultrasonic echography in the mare. J. Reprod. Fert., Suppl. 32, 423-430.

Cheung, A.T.W. Liu, I.K.M., Walsh, E.M. and Miller, M.E. (1985): Phagocytic and killing capacities of uterine-derived polymorphonuclear leukocytes from mares resistant and susceptible to chronic endometritis. Am. J. vet. Res. 46, 1938-1940.

Crouch, J.R.F., Atherton, J.G. and Platt, H. (1972): Venereal transmission of Klebsiella aerogenes in a Thoroughbred stud from a persistently infected stallion. Vet. Rec., 90, 21.

Crowhurst, R.C., Simpson, D.J., Greenwood, R.E.S. and Ellis, D.R. (1979): Contagious equine metritis. Vet. Rec., 104, 465.

David, J.S.E., Frank, C.J., and Powell, D.G. (1977): Contagious metritis 1977. Vet. Rec., 101, 189. 
Dimock, W.W. and Edwards, P.R. (1927): Genital infections in mares by an organism of the encapsulatus group. J. Am. vet. med. Ass. 70, 469-480.

Dimock, W.W. and Edwards, P.R. (1928): Pathology and bacteriology of the reproductive organs of mares in relation to sterility. Res Bull. Ky agric. exp. Stn, 286.

Farrely, B.T. and Mullaney, P.E. (1964): Cervical and uterine infection in Thoroughbred mares. Ir. vet. J., 18, 201

Finn, C.A. and Porter, D.G. (1975): Uterine function in aged animals. In: The Uterus. Pubs. Elek Science, London. 100-103.

Guerin, G., Bertaud, M. and Amigues, Y. (1994): Characterisation of seven new horse microsatellites: HMS1. HMS2, HMS3, HMS5, HMS6, HMS7 and HMS8. Animal Genetics, 25, 62.

Hazard, G.H., Hughes, K.L. and Penson, P.J. (1979): Contagious equine metritis in Australia. J. Reprod. Fert., Suppl. 27, 337

Hughes, J.P., Loy, R.G., Atwood, C., Astbury, A.C. and Burd, H.E. (1966): The occurrence of Pseudomonas in the reproductive trac of mares and its effect on fertility. Cornell vet., 56, 595.

Hughes, J.P. and Loy, R.G. (1969): Investigations on the effect of intrauterine inoculations of Streptococcus zooepidemicus in the mare. Am. Ass. equine Practnrs, 15, 289.

Hunt, M. and Rossdale, P.D. (1963): A specific venereal disease of Thoroughbred mares. Vet. Rec., 75, 1092.

Kenney, R.M. (1975): Prognostic value of endometrial biopsy in the mare. J. Reprod. Fert. Suppl 23, 347-348.

Kenney, R.M. (1978): Cyclic and pathologic changes in the mares endometrium as detected by biopsy, with a note on early embryonic death. J. Am. vet. med. Assoc. 172, 241-262.

Kenney, R.M., Bergman, R.V., Cooper, W.L. and Morse, G.W. (1975): Minimal contamination techniques for breeding mares: technique and preliminary findings. Am. Ass. equine Practnrs, 21, 327.

Klemetsdal, G. (1990): Breeding for performance traits in horses - a review. Proceedings, 4th World Congress on Genetics Applied to Livestock Production, 16, 184-193.

Knudsen, O. (1964): Endometrial cytology as a diagnostic aid in ma res. Cornell Vet. 54, 415-422

LeBlanc, M.M., Ward, L., Tran, T. and Widders, P. (1991): Identification and opsonic activity of immunoglobulins recognising Streptococcus zooepidemicus antigens in uterine fluid of mares. J. Reprod. Fert. Suppl. 44, 289-296

LeBlanc, M.M., Neuwith, L., Asbury, A.C., Tran, T., Mauragis, D. and Klapstein, E. (1994a): Scintigraphic measurement of uterine clearance in normal mares and mares with recurrent endometritis. Equine vet. J. 26, 109-113.

LeBlanc, M.M., Neuwirth, L., Mauragis, D., Klapstein, E. and Tran, T. (1994b): Oxytocin enhances clearance of radiocolloid from the uterine lumen of reproductively normal and infertile mares. Equine vet. J. 26, 279-282.

Marti, E., Gerber, H., Essich, G., Oulehla, J. and Lazary, S. (1991): The genetic basis of equine allergic diseases 1 . Chronic hypersensitivity bronchitis. Equine vet J., 23, 457-460.

Marti, E., Gerber, H. and Lazary, S. (1992): On the genetic basis of equine allergic diseases: II. Insect bite dermal hypersensitivity Equine vet. J. 24, 113-117.

Marti, E. and Binns, M. (1997): Horse genome mapping: A new era in horse genetics? Equine vet. J. 29 (in press).

Mather, E.C., Refsal, K.R., Gustafsson, B.K., Seguin, B.E. and Whitmore, H.L. (1979): The use of fibre-optic techniques in clinical diagnosis and visual assessment of experimental intrauterine therapy in mares. J. Reprod. Fert. Suppl. 27, 293-297.

Merkt, H. W. Bisping, A. R. Günzel and G. Kirpal (1980): Die Tupfer probe in der gynäkologischen Untersuchung der Stute. Der prakt. Tierarzt, 301-307

Merkt, H., A. Wöckener, T. Heilenbrinker und M. Zemke (1987): Mikrobielle Untersuchung in der Stutengynäkologie. Der prakt. Tierarzt, 5-12

Palmer, E. and Driancourt, M.A. (1980): Use of ultrasonic echography in equine gynaecology. Theriogenology 13, 203-216.

Pascoe, R.R. (1979): Observations on the length and angle of declination of the vulva and its relation to fertility in the mare. J. Reprod. Fert. Suppl. 27, 299-305

Peterson, F.B., McFeely, R.A. and David, J.S.E. (1969): Studies on the pathogenesis of endometritis in the mare. Am. Ass. equine Practnrs, 15, 279

Platt, H., Atherton, J.G. and Simpson, D.J. (1978): The experimental infec tion of ponies with contagious equine metritis. Equine vet. J., 10, 153.

Platt, H., Atherton, J.G. and Simpson, D.J., Taylor, C.E.D., Rosenthal, R.O., Brown, D.F.J. and Wreghitt, T.G. (1977): Genital infection in mares. Vet. Rec., 101, 20.
Pouret, E.J.M. (1982): Surgical tecnique for the correction of pneumo- and urovagina. Equine vet. J. 14, 249.

Powell, D.G., David, J.S.E. and Frank, C.J. (1978): Contagious equine metritis. The present situation reviewed and a revised code of practice for control. Vet. Rec., 103, 399.

Ricketts, S.W. (1975): Endometrial biopsy as a guide to diagnosis of endometrial pathology in the mare. J. Reprod. Fert. Suppl. 23, 341-345.

Ricketts, S.W. (1976): Klebsiella aerogenes in mares. Vet. Rec., 99, 489.

Ricketts, S.W. (1978): Histological and Histopathological Studies of the Endometrium of the Mare. Dissertation, Royal College of Veterinary Surgeons for the Diploma of Fellowship.

Ricketts, S.W. (1987): Perineal conformation abnormalities. In: Current Therapy in Equine Medicine 2. Ed. N.E. Robinson, Pubs. W.B. Saunders, Philadelphia. 518-520.

Ricketts, S.W. and Alonso, S. (1991): The effect of age and parity on development of equine chronic endometrial disease. Equine vet J. 23(3), 189-192.

Ricketts, S.W., Young, A. and Medici, E.B. (1993): Uterine and clitoral cultures. In: Equine Reproduction. Eds. MCKinnon A.O. and Voss, J.L. Pubs. Lea and Febiger, Philadelphia, London, 234-245.

Ricketts, S.W., Rossdale, P.D., Wingfield-Digby, N.J., Falk, M.M., Hopes, R., Hunt, M.D.N. and Peace, C.K. (1977): Genital infection in mares. Vet. Rec., 101, 65.

Rossdale P.D. and Ricketts, S.W. (1980): Infertility/subfertility in the mare. In: Equine Stud Farm Medicine. Balliere Tindall, London. 53-119.

Rossdale, P.D. (1988): Experience in veterinary practice: Knowledge comes but wisdom lingers. Vet. Rec. 122(3), 67-70.

Rowson, L.E.A., Lamming, G.E. and Fry, R.M. (1953): The relationship between ovarian hormones and uterine infection. Vet. Rec., 65, 335.

Samuel, Carole A., Ricketts, S.W., Rossdale, P.D., Steven, D.H. and Thurley, K.W. (1979): Scanning electron microscope studies of the endometrium of the cyclic mare. J. Reprod. Fert. Suppl. 27, 287-292.

Simpson, D.J., Greenwood, R.E.S., Ricketts, S.W., Rossdale, P.D., Sanderson, M. and Allen, W.R. (1982): Use of ultrasound echography for early diagnosis of single and twin pregnancy in the mare. J. Reprod. Fert., Suppl. 32, 431-439.

Taverne, M.A.M., van der Weyden, G.C., Fontijne, P., Dieleman, S.J., Paschen, R.L. and Allen, W.R. (1979): In-vivo myometrial electrical activity in the cycling mare. J. Reprod. Fert. Suppl. 56, 521-532

Taylor, C.E.D., Rosenthal, R.O., Brown, D.F.J., Lapage, S.P., Hill, L.H. and Legross, R.M. (1978): The causative organism of contagious equine metritis 1977 - proposal for a new species to be known as Haemophilus equigenitalis. Equine vet. J., 10, 136.

Troedsson, M.H.T., Irwin, K.M.L.. Ing, M. and Pascoe, J. (1995): Smooth muscle electrical activity in the oviduct, and the effect of oxytocin, prostaglandin $\mathrm{F} 2 \mathrm{a}$, and prostaglandin $\mathrm{E} 2$ on the myometrium and the oviduct of the cycling mare. Biol. Reprod. Mono. 1, 475-488.

Watson, E.D., Stokes, C.R. and Boume, F.J. (1987): Uterine cellular and humoral defence mechanisms in mares susceptible and resistant to persistent endometritis. Vet. Immunol. Immunopathol. 16, 107-121.

Widders, P.R., Stokes, C.R., David, J.S.E and Bourne, F.J. (1984): Quantitation of the immunoglobulins in reproductive tract secretions of the mare. Res. vet. Sci. 37, 324-330.

Wingfield Digby, N.J. (1978): Studies of endometrial cytology in mares. Equine vet. J. 10, 167-170

Wingfield Digby, N.J. and Ricketts, S.W. (1982): Results of concurrent bacteriological and cytological examinations of the endometrium of mares in routine stud farm practice 1978-1981. J. Reprod. Fert., Suppl. $32,181-185$.

\section{Acknowledgements}

The author first met Professor Hans Merkt at his Newmarket clinic in June 1963. In the 34 years since that time a deep tinkage and friendship has developed in terms of family and clinical science. I am most grateful to the organisers of the meeting for providing this opportunity to express my respect and admiration for a colleague of immense standing and reputation within the field of my own interest, equine reproduction.

\section{Dr. Peter Rossdale}

Beaufort Cottage Stables

High Street

Newmarket, Suffolk

CB8 8JS, UK

Tel. $0044-1638-663150$

Fax: 0044-1638-660157 